https://nv.nltu.edu.ua

https://doi.org/10.15421/40290512

$@ \bowtie$ Correspondence author

Article received 14.05.2019 p.

Article accepted 30.05.2019 p.

V. Yu. Yukhnovskyi

yukhnov@ukr.net

Удк 630*[114+38]:582.632.2

І. А. Проценко, Г. О. Лобченко, В. Ю. Юхновський

Національний університет біоресурсів і природокористування України, м. Київ, Україна

\title{
ОСОБЛИВОСТІ РОСТУ ТА ФІТОМЕЛІОРАТИВНІ ВЛАСТИВОСТІ НАСАДЖЕНЬ ДУБА ЧЕРВОНОГО НА РЕКУЛЬТИВОВАНИХ ЗЕМЛЯХ ЧЕРКАЩИНИ
}

Проведено ретроспективний аналіз вирощування дуба червоного на території України та Європи, а також сучасні наукові дослідження щодо інвазійності цього виду. Виявлено, що для більшості країн Європи дуб червоний віднесено до інвазійних видів через високу конкурентоздатність природного поновлення та значне притінення поновлення автохтонних видів. Окрім цього, відзначено негативний вплив на грунт через підвищення кислотності, однак на кислих грунтах, староорних i деградованих землях дуб червоний має низку переваг порівняно із автохтонними видами. Узагальнено, що поширення дуба червоного на території України має безсистемний характер і найбільша його частка зосереджена у Західному Лісостепу. На території Черкащини зростає всього 3 \% насаджень за його участі, а у межах Юрківського буровугільного кар'єру на насадження дуба червоного припадає тільки 2,2 \%. Встановлено, що на рекультивованих землях Юрківського буровугільного кар'єру дуб червоний, як фітомеліорант, має кращі грунтополіпшувальні властивості порівняно із хвойними, однак гірші порівняно з іншими листяними видами. Виявлено, що порівняно із дубом звичайним модельні дерева дуба червоного характеризуються вищою повнодеревністю стовбура і кращими показниками росту і продуктивності після III класу віку, коли коренева система не отримує належної кількості поживних речовин.

Ключові слова: інтродуцент; інвазія; повнодеревність; збіг стовбура; фітомеліорант.

Вступ. Останнім часом серед учених і практиків лісівників Свропи триває дискусія щодо використання дуба червоного Quercus rubra Du Rei у лісових насадженнях. Дуб червоний дедалі частіше згадують в Україні та за кордоном як інвазійний та небезпечний вид. Водночас біоекологічні особливості дуба червоного мають низку переваг для вирощування його як швидкорослого та невибагливого до трофності грунту виду. На території України серед інтродукованих видів дуб червоний $є$ найпоширенішим видом за площею насаджень 3 його участю, однак його територіальний розподіл не $\epsilon$ рівномірним. Тож питання вивчення досвіду і перспектив використання його у лісових насадженнях різного призначення у різних умовах є досі відкритим.

Історично зафіксовано, що дуб червоний з'явився на території Свропи в наприкінці XVII ст. Північноамериканський вид спершу було інтродуковано у Швейцарії, потім у Бельгії та Голландії. Як у Західній Свропі, так і на території України дуб червоний спочатку вводили у паркові насадження як декоративний вид і тільки наприкінці ХІХ ст. - у лісові культури.

Перший досвід вирощування дуба червоного вказував про низку його переваг порівняно із місцевим видом - дубом звичайним, що проявилося у вищій зимос- тійкості, інтенсивнішому рості, невибагливості до грунтових і гідрологічних умов, особливо на грунтах легкого механічного складу. Дуб червоний відзначається рясним насіннєношенням і високою паросткотвірною здатністю. Негативних відгуків набула якість деревини дуба червоного, оскільки вона характеризується вищою шпаруватістю та нижчою щільністю, однак на противагу цій думці висловлювалося припущення про високу якісь деревини у насадженнях, вирощених у відповідних лісорослинних умовах. У цьому контексті зазначається те, що клімат Європи сприятливіший для випрошування цього виду, ніж на його батьківщині. На території України площа лісів, сформованих за участі дуба червоного як інтродуцента, поступово зростала і вже на середину XX ст. їх площа становила близько 10 тис. га. 3 прийняттям низки нормативних документів, зокрема рішення технічної ради Головного Управління лісового господарства та лісозаготівель при Раді Міністрів УРСР від 1959 р. та наказу Міністра лісової і деревообробної промисловості СРСР від 1975 р. щодо віднесення дуба червоного до швидкорослих порід, його почали масового вводити у лісовий фонд України.

Нині дуб червоний розглядають як інвазійний вид у багатьох країнах Європи. Зокрема, у роботі литовських

\section{Інформація про авторів:}

Проценко Ігор Анатолійович, аспірант, кафедра відтворення лісів та лісових меліорацій. Email: protiga4@gmail.com

Лобченко Ганна Олександрівна, канд. с.-г. наук, доцент, кафедра відтворення лісів та лісових меліорацій.

Email: lobchenko@nubip.edu.ua

Юхновський Василь Юрійович, д-р с.-г. наук, професор, кафедра відтворення лісів та лісових меліорацій. Email: yukhnov@nubip.edu.ua

Цитування за ДСту: Проценко І. А., Лобченко Г. О., Юхновський В. Ю. Особливості росту та фітомеліоративні властивості насаджень дуба червоного на рекультивованих землях Черкащини. Науковий вісник НлтУ України. 2019, т. 29 , № 5. С. 60-65.

Citation APA: Protsenko, I. A., Lobchenko, G. O., \& Yukhnovskyi, V. Yu. (2019). Some features of growth and phytomeliorative properties of red oak in recultivated lands in Cherkasy region. Scientific Bulletin of UNFU, 29(5), 60-65.

https://doi.org/10.15421/40290512 
вчених (Riepšas \& Straigyte, 2008) досліджено вплив інтродукованих видів на біорізноманіття місцевих екосистем у лісах Литви, де дуб червоний зростає на площі 116 га. Встановлено, що поширення дуба червоного відбувається інтенсивніше, ніж дуба звичайного у бідніших умовах трофності, а також існує негативний влив на трав'яну флору та мікробіоценоз, що розкладає і перетворює органічну масу в доступну для рослин форму, а відтак меншим $є$ вміст поживних речовин у грунті. Для дуба червоного в умовах Литви визначено рівень інтенсивності інвазії вище середнього й обгрунтовано думку щодо екологічної та економічної недоцільності лісовирощування інтродуцента та рекомендовано для вирощування тільки з метою озеленення урбанізованих територій.

Подібна ситуація склалася у білоруській частині Біловезької Пущі, де дуб червоний зростає на площі понад 220 га і характеризується високою продуктивністю (переважно I класом бонітету). Експансія цього виду відбувається у відносно бідних умовах, де для нього менше конкурентів. Відзначається поява підросту дуба червоного у чистих сосняках орлякових та зеленомошних.

Польські вчені Woziwoda, Kopeć \& Witkowski (2013) встановили, що дуб червоний має негативний вплив на лісові ценози, оскільки зменшує видове різноманіття та рясність як на ділянках лісовідновлення, так і лісорозведення, особливо на староорних землях. На їхню думку, жоден місцевий вид судинних рослин не проявляє переваг від введення дуба червоного і тільки кілька рослин здатні $з$ ним співіснувати. Також природне поновлення автохтонних видів лімітоване через їх притінення інвазійним видом. Однак вирощування насаджень за участі швидкорослого дуба червоного є економічно вигідним, оскільки дає змогу продукувати деревину й отримувати екосистемі послуги. Важливим $\epsilon$ висновок також про те, що дуб червоний забезпечує більшу біопродуктивність на староорних землях, ніж дуб звичайний, однак гальмує процес формування лісового середовища.

У роботах чеських вчених Miltner \& Kupka (2016) 3 лісівничої точки зору дуб червоний розглядають для заліснення посушливих та кислих грунтів, оскільки за таких умов цей вид має рясне насіннєношення, а отже гарантоване успішне поновлення, а сіянці дуба формують стрижневу кореневу систему, що дає змогу переносити посуху навіть у перший рік після проростання. Також зазначається висока стійкість до вітровалів, які значно впливають на ведення господарства у Чехії, а отже, домішка дуба червоного сприятиме підвищенню стійкості насаджень загалом. Дуб червоний вирощували у посушливих умовах для заміщення автохтонних видів дуба, що зазнали масового всихання.

Ці самі вчені (Miltner, Kupka \& Třšstík, 2016) описують негативний вплив дуба червоного на верхній родючий шар лісового грунту порівняно 3 автохтонними видами дуба, зокрема, це має прояв через підвищену кислотність, нижчу реакцію грунту та менший вміст основ i поживних речовин як загалом, так і в доступних для рослинності формах у верхньому шарі грунтового профілю. Тож за винятком спустошених та девастованих грунтів, призначених для лісової рекультивації, цей вид спричиняє деградацію грунтових умов. Зазначено, що дуб червоний відіграє значну роль у формуванні лісо- вих насаджень та покращенні грунтових умов на девастованих та деградованих грунтах, оскільки є стійкішим до подібних жорстких умов родючості. У Чехії вивчено також вплив різних видів на грунт під час лісорозведення на староорних землях. Дуб червоний мав сприятливіший вплив на грунт щодо показників кислотності та вмісту поживних речовин порівняно із хвойними видами, але гірший, ніж з березою. Вважають, що дуб червоний вибагливіший до вмісту поживних речовин, а отже, може спричиняти зниження вмісту азоту.

Отже, інвазійність дуба червоного у лісових насадженнях Європи зумовлена високою здатністю до розмноження (насіннєва та порослева) дуба червоного, а також вищою конкурентоспроможністю порівняно із автохтонними видами Свропи. Так, у досліджених твердолистяних насадженнях Німеччини встановлено, що природне поновлення дуба червоного найуспішніше порівняно з усіма іншими видами разом взятими. Чисельність поновлення зменшувалась на віддалі від насінника та на родючих грунтах із високим вмістом кальцію. За даними польського вченого Chmura (2013), дуб червоний $є$ конкурентоспроможним серед видів лісового біогеоценозу як у старшому віці, так і на етапі сходів та сіянців, а отже, може впливати на зниження біорізноманіття підліску і надгрунтового покриву.

Встановлено, що на поширення дуба червоного також впливають тварини. Зокрема, дослідженнями Myczko, Dylewski, Zduniak, Sparks \& Tryjanowski (2014) встановлено, що сойка надає перевагу жолудям автохтонних видів дуба із меншим вмістом танінів, однак із зменшенням їх кількості восени відбувається активне накопичення і розповсюдження жолудів дуба червоного. Домінування дуба червоного у підрості свідчить про ефективність поширення його сойками, навіть за незначної представленості деревного виду у деревостані. Отже, сойка може істотно впливати на видові зміни у лісах Свропи, на відміну від ситуації у природному ареалі дуба червоного. А за даними бельгійських науковців, найсприятливішим чинником поширення дуба червоного є гризуни, зокрема щурі, білки, лісові миші та дикий кабан.

Щодо сучасного стану в Україні варто зазначити, що нині дуб червоний $є$ найпоширенішим інтродукованим деревним видом у лісових культурах України (45 тис. га), а найбільші площі лісових насаджень зосереджені саме у Західних областях, зокрема на Львівщині (13 тис. га) та Івано-Франківщині (6 тис. га) (Shvets, Kahaniak \& Hrynyk, 2001). Якщо ж проаналізувати розподіл площі насаджень за участі дуба червоного у межах природно-кліматичних зон, то найбільша його частка у Лісостеповій зоні (80 \%), менше у Поліссі (17\%) і зовсім не значна частка у Степу - до $3 \%$.

За даними аналізу лісівничо-таксаційних показників для лісових насаджень із участю дуба червоного на території Страдчівського навчально-виробничого лісокомбінату НЛТУ України (Debrynyuk \& Prydka, 2013), встановлено, що найбільша частка лісових насаджень зростає в умовах свіжого сугруду, де і відбувається накопичення найбільших обсягів деревини для дуба червоного, тож саме в таких умовах можливе плантаційне вирощування інтродуцента. Також автори слушно висловлюють думку щодо недоцільності вирощування дуба червоного в умовах діброви, де він $\epsilon$ конкурентом для автохтонного дуба звичайного. 
Інвазійність досліджуваного виду на території України існує в об'єктах природозаповідного фонду, де важливим $\epsilon$ визначення впливу інтродукованих видів на навколишнє середовища i збереження у природному стані типових або унікальних для цієї ландшафтної зони природних комплексів. Колектив учених Strymets, Pogorilko \& Khomin (2017) дослідив роль дуба червоного у лісових насадженнях заповідника "Розточчя", де було прийнято рішення щодо вилучення цього виду із заповідної території ще у 1999 р. Визначено, що біорізноманіття трав'яного покриву під наметом дуба червоного зріджене, зникають рідкісні види, окрім цього, природне поновлення відбувається на відстані понад 500 м від материнського деревостану, тобто має інвазійний характер.

Та на противагу екологічному впливу дуба червоного на заповідних територіях, у наукових роботах вітчизняних учених наводять дані щодо комплексу переваг вирощування цього виду у лісових насаджень експлуатаційного та захисного призначення. Зокрема, піднаметові культури дуба червоного (Rybak, Rybak \& Yukhnovskyi, 2017) у чистих сосняках мають позитивний вплив як на фізико-хімічні властивості грунтів, так і на основний деревостан. Під їх впливом збільшується частка підстилки інтенсивного розпаду, підвищується вміст гумусу на 0,4 \%, зростає біорізноманіття мікробіоценозу та зооценозу, підвищується продуктивність лісостанів і покращується товарна структура соснових деревостанів. Автори рекомендують вводити дуб червоний під наметом сосняків рядами шпигуванням жолудів або садінням сіянців залежно від ступеня задерніння, а після рубки основного деревостану відновлювати сосну звичайну між рядами дуба червоного, періодично проводячи рубки догляду і залишаючи в складі до 2 одиниць дуба червоного.

За даними П. Г. Вакулюка, дуб червоний в умовах свіжого субору та судіброви не рекомендовано вводити кулісами, оскільки він витісняє сосну звичайну, відтак рекомендує вводити його ланками або одним рядом. Також на староорних землях і пісках із ознаками враження сосняків кореневою губкою у вікнах вирубаного сухостою рекомендує вводити дуб червоний у комбінації з чагарниками чи супутніми породами. Також дуб червоний рекомендований для протипожежних куліс, захисних насаджень на яружно-балкових системах, полезахисних і стокорегулювальних смуг.

Мета роботи - вивчення досвіду вирощування насаджень за участі дуба червоного в Україні та Європі, а також дослідження його фітомеліоративних властивостей та особливостей росту на рекультивованих землях териконів і відвалів розкривних порід у межах Юрківського буровугільного кар'єру.

Матеріали та методика дослідження. Об'єктом дослідження є насадження дуба червоного на території лісомеліоративного фонду (рекультивованих землях) Юрківського буровугільного кар'єру. Для визначення місця дуба червоного у лісових насадженнях вивчено досвід вирощування цієї породи як інтродуцента на території Європи і в Україні.

Для встановлення фітомеліоративних властивостей дуба червоного порівняно з іншими деревними видами використано експериментальні дані 31 дослідної ділянки щодо вмісту поживних речовин у грунтах рекультивованих ландшафтів Юрківського буровугільного ба- сейну. У цій роботі увагу зосереджено на екологічних (продукційній та геохімічній) фітомеліоративних властивостях насаджень із участю дуба червоного і доповнена даними щодо агротехніки створення дослідних насаджень та особливостей росту дуба червоного.

Для вивчення перспектив вирощування дуба червоного на рекультивованих землях виконано аналіз особливостей його ходу росту на досліджуваній території, а також виконано порівняння із ростом у цих же умовах дуба звичайного (Quercus robur L.). Для дослідження таксаційних показників росту було закладено дві тимчасові пробні площі: у 49-річному насадженні зі складом 9Дч1Дз та у 40-річному насадженні зі складом

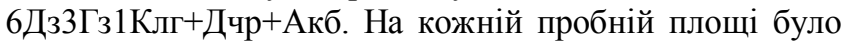
відібрано по одній середній моделі та виконано детальний аналіз ходу росту цих дерев.

Результати дослідження та їх обговорення. У межах Черкаської обл., де розміщений Юрківський буровугільний кар'єр, дуб червоний займає понад 1087 га у лісових насадженнях, з яких чисті насадження становлять тільки 4,3 \%. У межах Лісостепової зони на Черкащину припадає всього 3 \% від площі насаджень дуба червоного. За віковою структурою переважають молодняки - $93 \%$, з яких $31 \%$ насадження віком до 20 років і $62 \%$ насадження віком 21-40 років, решту $7 \%$ займають середньовікові насадження та 0,1\% насадження старші 61 року (Majboroda, 2011). 3 такого розподілу можна зробити висновок, що до $50-x$ років дуб червоний на Черкащині вводили у лісові культури поодиноко, у період між 50 і 70-ми роками процес інтродукції в регіоні став інтенсивнішим, однак пік створення лісових культур з участю дуба червоного припадає на 8090-ті роки, а вже у незалежній Україні площа насаджень дуба червоного скоротилася вдвічі порівняно 3 попереднім періодом. За показниками запасу стовбурної деревини чисті насадження дуба червоного віком до 20 років мають запас $39 \mathrm{~m}^{3} \cdot \mathrm{ra}^{-1}$, у віці 21-40 років $137 \mathrm{~m}^{3} \cdot \mathrm{ra}^{-1}$, у віці 41-60 років $-230 \mathrm{~m}^{3} \cdot \mathrm{ra}^{-1}$, та у віці понад 61 рік - $300 \mathrm{~m}^{3} \cdot \mathrm{ra}^{-1}$. Варто заначити, що для Львівщини, де зростає найбільша площа насаджень дуба червоного, показник запасу до 40 років вищий на третину, порівняно із насадженнями на Черкащині, однак у віці понад 41 рік запаси зрівнюються.

У лісомеліоративному фонді Юрківського буровугільного кар'єру дуб червоний представлений на 9 ділянках загальною площею 14,1 га, що становить 2,2 \% від загальної площі лісомеліоративного фонду (таблиця). Частка дуба червоного у складі деревостанів змінюється від 10 до $90 \%$, а також на трьох ділянках до $5 \%$. У трьох із вказаних насаджень закладено тимчасові пробні площі (ТПП № 8, 15 та 27) і проведено детальний аналіз фізико-хімічних показників зразків грунту.

Агротехніка вирощування дуба червоного потребує врахування його біоекологічних особливостей, зокрема у межах природного ареалу цей вид зростає за щорічних опадів у кількості 627-1214 мм. Відтак переваги у вирощуванні має садивний матеріал у вигляді жолудів, ніж сінців і саджанців, оскільки в такому випадку дуб формує стрижневу кореневу систему, а тому має можливість підвищити стійкість рослини в умовах нестачі вологи, що часто трапляється на відвальних площах. Однак у степовій зоні дуб червоний недоцільно вирощувати у лісових культурах. Результати досліджень вирощування дуба червоного на відвальних суглинках 
Юрківського буровугільного розрізу у Лісостеповій зоні, проведені F. Brovko (2012), показали, що дуб червоний має кращі показники росту порівняно із дубом звичайним. У молодих насадженнях деревний запас дуба червоного майже на третину вищий, ніж дуб звичайного. До того ж дуб червоний притінює і цим самим пригнічує ріст автохтонного виду.

Таблиця. Таксаційна характеристика лісових насаджень на рекультивованих землях із участю дуба червоного

\begin{tabular}{|c|c|c|c|c|c|c|c|c|c|}
\hline Квартал & $\begin{array}{l}\text { Ви- } \\
\text { діл }\end{array}$ & $\begin{array}{c}\text { Площа, } \\
\text { га }\end{array}$ & Бонітет & Склад & $\begin{array}{c}\text { Вік, ро- } \\
\text { ків }\end{array}$ & $\begin{array}{c}\text { Висота, } \\
\text { м }\end{array}$ & $\begin{array}{c}\text { Діаметр, } \\
\text { см }\end{array}$ & Повнота & Примітка \\
\hline 82 & 2 & 4,4 & I & 7Сз1Дчр 2Клг+Кля & \begin{tabular}{|l|}
38 \\
\end{tabular} & 15 & 18 & 0,7 & ТПП 8 \\
\hline 83 & 2 & 4,5 & 1 & 7Сз2Клг 1Дчр+Кля & 38 & 14 & 18 & 0,7 & \\
\hline 83 & 4 & 1 & II & 8Дчр2Акб +Брс & 13 & 2,5 & 2 & 0,7 & \\
\hline 83 & 5 & 1,3 & 1 & 5Дз2Дчр 3Лпд & 38 & 14 & 16 & 0,8 & \\
\hline 84 & 13 & 0,3 & II & 10Дз+Дчр +Сз+Акб & 38 & 12 & 14 & 0,7 & \\
\hline 86 & 4 & 1,1 & $\mathbf{I}$ & 6Дз3Гз1Клг +Дчр+Акб & 40 & 15 & 18 & 0,6 & ТПП 15 \\
\hline 90 & 1 & 0,6 & II & 3Дз3Дчр 4Акб & 49 & 14 & 16 & 0,7 & \\
\hline 90 & 3 & 0,5 & I & 9Дчр1Д3 & 49 & 21,0 & 20,5 & 0,8 & ТПП 27 \\
\hline 90 & 5 & 0,4 & $1 \mathrm{~A}$ & 7Скр2Клг 1Лпд+Дчр+Бп & 38 & 16 & 18 & 0,6 & \\
\hline \multicolumn{2}{|c|}{ Разом } & 14,1 & - & - & - & - & - & - & - \\
\hline
\end{tabular}

Насадження на пробних площах створено із проведенням осінньої суцільної оранки на глибину 20-26 см і весняною культивацією з боронуванням механізовано однорічними сіянцями із розміщенням посадкових місць 2,5×0,5 м. У насадженні на ТПП 8 дуб червоний вводили 3-рядною кулісою, що чергується із аналогічною кулісою клена гостролистого і у віці 38 років має склад 7Сз1Дчр2Клг+Кля. Насадження на ТПП 15 створювалося кулісами дуба звичайного та граба звичайного, однак у віці 40 років шляхом природного поновлення клена гостролистого, дуба червоного та робінії псевдоакації від сусідньої стіни лісу сформувався такий склад деревостану 6Дз3Гз1Клг+Дчр+Акб. Насадження на ТПП 27 має у складі 9Дчр1Дз, хоча воно створене чистими культурами із введенням чагарників, який до 49-річного віку лісостану повністю випали.

Встановлено, що у грунтових зразках, відібраних під наметом насаджень дуба червоного та його куліс, найнижчий вміст фосфору і калію. Водночас вміст загального азоту у грунті, відібраного в насадженнях дуба червоного, перевищує аналогічний показник хвойних насаджень, однак нижчий, ніж в інших листяних лісостанах. У кулісі дуба червоного виявлено вищий вміст гумусу, ніж під наметом лісостану. Останнє, очевидно, зумовлено надходженням світла, що сприяє інтенсивнішій мінералізації підстилки у кулісах порівняно 3 товстішим шаром підстилки під наметом зімкнутого насадження. Водночас, у кулісах дуба червоного спостерігається інтенсивне розростання підросту.

Для таксаційного аналізу росту дуба червоного та дуба звичайного на закладених тимчасових пробних площах ТПП 15 та ТПП 27 було зрубано по одному модельному дереву та виконано детальний аналіз їхнього ходу росту.

Найповнішою характеристикою форми стовбура $є$ збіг, абсолютний і відносний. Відношення двох діаметрів, взятих на відносних висотах, називають класом форми $(q)$, а деталізований набір цих співвідношень із загальним знаменником - числами збігу. Ці величини характеризують форму стовбура або його збіжність, на відміну від видових чисел, які характеризують тільки повнодеревність стовбура. Порівняння твірних поверхонь стовбурів 40-річних модельних дерев дуба звичайного та дуба червоного, які зростають в однакових умовах на території буровугільного кар'єру, зображено на рис. 1. Дані цього рисунку свідчать про те, що твірна поверхня стовбура дуба червоного характери- зується меншим збігом, ніж твірна поверхня стовбура дуба звичайного.

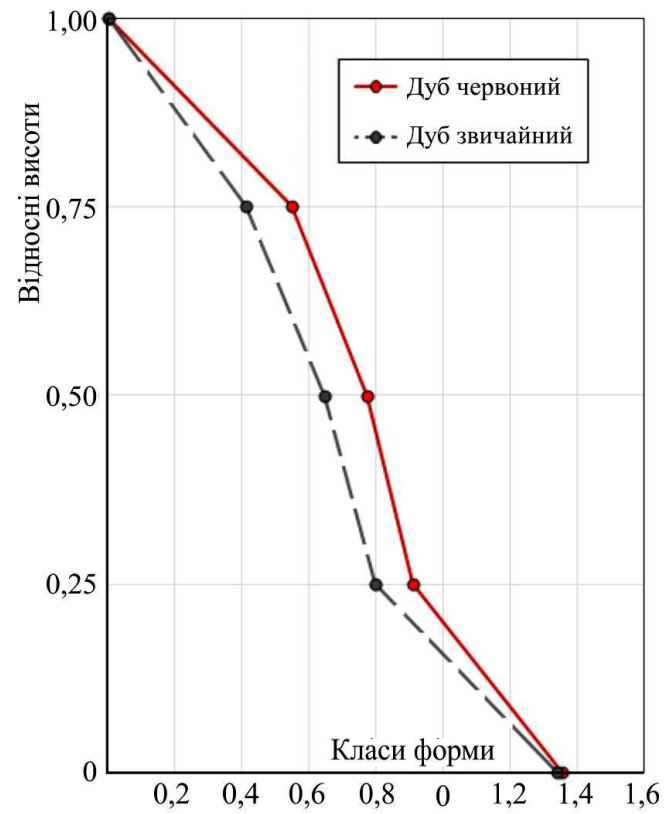

Рис. 1. Твірна поверхня стовбурів модельних дерев дуба червоного та дуба звичайного, які зростають на території Юрківського буровугільного кар'єру

Так, середнє значення нульового класу форми $q_{0,0}$ стовбура дуба звичайного на $1,1 \%$ менше, ніж відповідне значення дуба червоного, $q_{0,25}-$ на $12,2 \%, q_{0,5}-$ на $16,4 \%, q_{0,75}$ - на $25,2 \%$. Також, щоб проаналізувати твірну поверхню досліджуваних деревних стовбурів було виконано обчислення показника твірної поверхні за рівнянням (1), розробленим для правильних тіл обертання, але яке дає змогу характеризувати форму деревного стовбура:

$$
y=a \cdot \sqrt[m]{x^{2}}
$$

де: $x$ - відстань від верхівки стовбура до відповідного перерізу; $a$ - параметр, який визначає розмір кривої; $m$ - показник твірної поверхні стовбура.

Виходячи із наведеної вище формули, враховуючи особливості лісотаксаційних вимірювань, було опрацьовано рівняння (2), яке дає змогу визначити показник твірної поверхні деревного стовбура:

$$
m=\frac{2 \cdot \lg d_{1}}{d_{2} \cdot \lg \left(\frac{L-l_{1}}{L-l_{2}}\right)}=\frac{2 \cdot \lg d_{1}}{d_{2} \cdot \lg \left(\frac{L-l_{E_{1}}}{L-l_{E_{2}}}\right)},
$$


де: $L$ - довжина стовбура; $l_{E_{1}}$ i $l_{E_{2}}-$ відносні відстані від нижнього перерізу стовбура до точки вимірювання діаметрів $d_{1,3}$ i $d_{0,5}$.

Отже, отримані показники твірної поверхні деревних стовбурів дуба червоного та дуба звичайного відповідно дорівнюють 1,0 (наближено відповідає твірній параболоїда) та 1,7 (наближено відповідає твірній конуса). Окрім цього, додатково було виконано аналіз показників твірної поверхні досліджуваних стовбурів у динаміці, тобто розраховано ці показники у віці дерева 10, 20, 30 і 40 років. Унаслідок цього, за показником твірної поверхні, стовбур дуба червоного, окрім 10- та 20-річного віку був наближеним до параболоїда, а стовбур дуба звичайного навпаки у 10-річному віці був наближеним до параболоїда, далі до конуса, нейлоїда і знову конуса. Зазвичай, за винятком молодняків, типова твірна поверхня стовбурів дерев дуба червоного є наближеною до параболоїда.

Щоб проаналізувати ріст модельних дерев, було виконано порівняння ходу росту модельних дерев за основними таксаційними показниками - видовим числом, об'ємом, діаметром стовбура на висоті 1,3 м та висотою (рис. 2, 3).

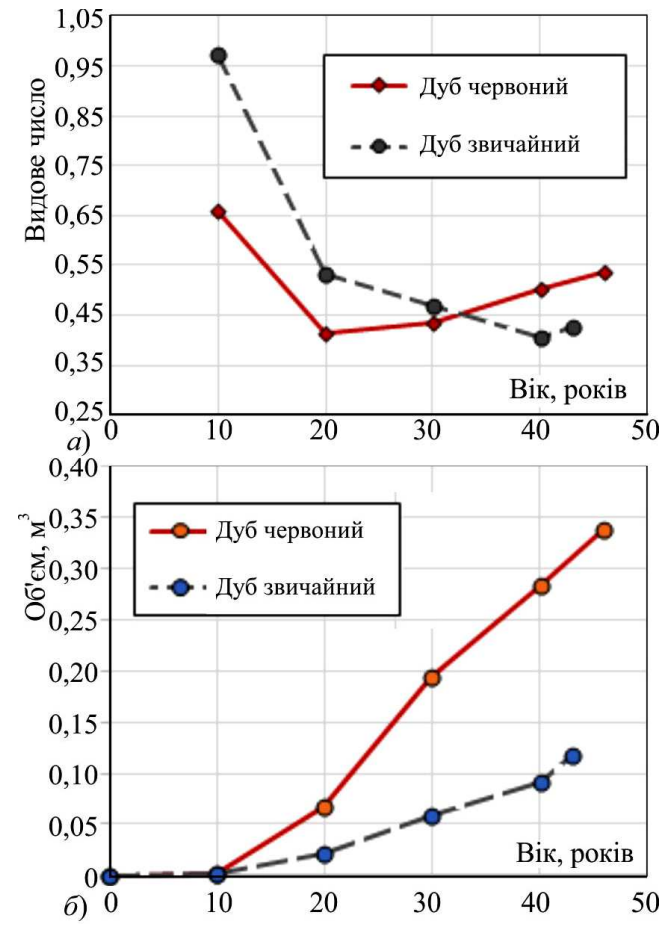

Рис. 2. Хід росту модельних дерев дуба червоного та дуба звичайного за видовим числом $(a)$ та об'ємом $(b)$

На рис. 2 видно, що дуб червоний характеризується набагато кращим ростом за об'ємом, ніж дуб звичайний. Різниця в об'ємі, починаючи із 20 річного віку, становить понад $60 \%$. Для того щоб оцінити не тільки абсолютні значення об'єму, а й врахувати його співвідношення $з$ діаметром та висотою, було проаналізовано видові числа. Отже, згідно з отриманими значеннями видових чисел, можна спостерігати, що до 30-річного віку стовбур модельного дерева дуба звичайного характеризується більшою повнодеревністю порівняно із стовбуром дуба червоного, але після 30-річного віку ситуація змінюється і видові числа дуба червоного перевищують відповідні значення для дуба звичайного.

Дані рис. 3 характеризують кращий ріст дуба червоного як за діаметром на висоті 1,3 м, так і за висотою.
Різниця між діаметрами стовбурів дерев на висоті 1,3 м, в різному віці, становила від 18 до $33 \%$, а різниця між висотами - 32-43\%, що вказує на значні переваги в рості дерев дуба червоного над дубом звичайним, які зростають в умовах Юрківського буровугільного кар'єру.
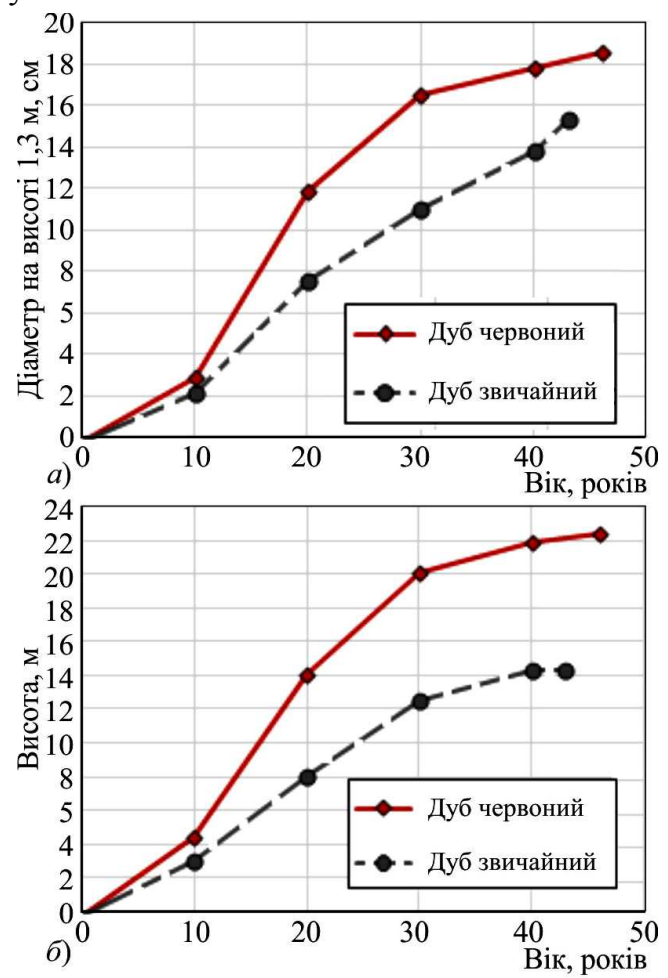

Рис. 3. Хід росту модельних дерев дуба червоного та дуба звичайного за діаметром на висоті 1,3 м $(a)$ і висотою $(b)$

Враховуючи наведені особливості, можна зробити висновок про істотну відмінність росту порівнюваних деревних видів в умовах буровугільного кар'єру. За таксаційними показниками росту дуб червоний є кращим та перспективнішим деревним видом, порівняно із дубом звичайним, для заліснення рекультивованих земель в умовах Юрківського буровугільного кар'єру.

Висновки. Дуб червоний інтродуковано у XIX ст. і за цей час набуто значного досвіду його лісовирощування. На території України і багатьох країн Свропи дуб червоний розглядають як інвазійний вид, оскільки він витісняє автохтонні види і цим знижує біорізноманіття у природних фітоценозів.

В умовах, де місцеві види не забезпечують виконання ними функцій, дуб червоний може бути незамінним, оскільки характеризується більшою пластичністю до грунтово-кліматичних умов порівняно із дубом звичайним і $є$ менш вибагливим до трофності грунту. Також природне поновлення дуба червоного конкурентоздатне і дає можливість лісовідновлення в умовах складного рельєфу.

Геохімічні властивості дуба червоного дещо кращі, ніж у хвойних видів, але гірші, ніж в інших листяних. Для сприяння гумусоутворення рекомендовано уникати вирощувати дуб червоний у чистих насадженнях, а вводити рядами чи вузькими кулісами для надходження світла і пришвидшення розкладу підстилки. Саме тому дуб червоний не може бути використаний як основний фітомеліорант для грунтополіпшення, однак його використання $є$ доцільним як протиерозійного, санітарного та протипожежного елементу насаджень. 
Дуб червоний на рекультивованих землях Юрківського буровугільного кар'єру, порівняно із дубом звичайним, характеризується більшою повнодеревністю стовбура. Окрім цього, властиві кращі показники росту у віці після 30 років, коли коренева система не отримуе належної кількості поживних речовин. Тому дуб червоний $€$ перспективним видом для вирощування на деградованих землях, однак потрібно забезпечити відстань від об'єктів природозаповідного фонду мінімум на 500 м для запобігання його поширенню у природні екосистеми.

\section{Перелік використаних джерел}

Brovko, F. M. (2012). Modern problems and achievements of forest reclamation of heap landscapes in Ukraine. (Ser. Forestry and Horticulture). Electronic Scientific Journal of National University of Life and Environmental Sciences of Ukraine, 1. [In Ukrainian].

Chmura, D. (2013). Impact of Alien Tree Species Quercus Rubra L. on Understorey Environment and Flora: a Study of the Silesian Upland (Southern Poland). Pol. J. Ecol., 61(3), 431-442.

Debrynyuk, M. Y., \& Prydka, P. P. (2013). Red oak (Quercus rub$r a \mathrm{~L}$.) in forest plantations Stradchivskiy TPFC: distribution and silvicultural-taxation specification. Scientific Bulletin of UNFU, 23(17), 9-14. [In Ukrainian].

Majboroda, V. A. (2011). Abundance and features of formation of age structure of forest stands of the oak red in Ukraine. Scientific Bulletin of UNFU, 21(3), 31-37. [In Ukrainian].

Miltner, S., \& Kupka, I. (2016). Silvicultural potential of northern red oak and its regeneration. J. For. Sci., 62(4), 145-152. https://doi.org/10.17221/115/2015-JFS
Miltner, S., Kupka, I., \& Třeštík, M. (2016). Effects of Northern red oak (Quercus rubra L.) and sessile oak (Quercus petraea (Mattusch.) Liebl.) on the forest soil chemical properties. Lesn. Cas. For. J., 62, 169-172. https://doi.org/10.1515/forj-2016-0020

Myczko, Ł., Dylewski, Ł., Zduniak, P., Sparks, T. H., \& Tryjanowski, P. (2014). Predation and dispersal of acorns by European Jay (Garrulus glandarius) differs between a native (Pedunculate Oak Quercus robur) and an introduced oak species (Northern Red Oak Quercus rubra) in Europe. Forest Ecology and Management, 331(1), 3539. https://doi.org/10.1016/j.foreco.2014.07.027

Riepšas, E., \& Straigytė, L. (2008). Invasiveness and Ecological Effects of Red Oaks (Quercus rubra L.) in Lithuanian Forests. Baltic Forestry, 14(2), 122-130.

Rybak, O. V., Rybak, V. O., \& Yukhnovskyi, V. Y. (2017). Undercanopy plantations of red oak in conditions of fairly infertile pine site type of Kiev Polissya. Kyiv: Kondor. [In Ukrainian].

Shvets, M. I., Kahaniak, Y. I., \& Hrynyk, H. H. (2001). The peculiarities of the northern red oaks widening on the territory of Ukraine. Scientific Bulletin of UNFU, 11(4), 38-41. [In Ukrainian].

Strymets, G. V., Pogorilko, V. V., \& Khomin, I. G. (2017). Introducents as a Result of Anthropogenic Transformation of Forests Under the Conditions of the Nature Reserve "Roztochya". Scientific Bulletin of UNFU, 27(10), 55-59. [In Ukrainian]. https://doi.org/10.15421/40271008

Woziwoda, B., Kopeć, D., \& Witkowski, J. (2013). The negative impact of intentionally introduced Quercus rubra L. on a forest community. Acta Soc Bot Pol., 83(1), 39-49. https://doi.org/10.5586/asbp.2013.035

I. A. Protsenko, G. O. Lobchenko, V. Yu. Yukhnovskyi

National University of Life and Environmental Sciences of Ukraine, Kyiv, Ukraine

SOME FEATURES OF GROWTH AND PHYTOMELIORATIVE PROPERTIES OF RED OAK IN RECULTIVATED LANDS IN CHERKASY REGION

A retrospective analysis of the cultivation of red oak on the territory of Ukraine and Europe, as well as modern scientific researches on the invasiveness of this species has been carried out. We have found that red oak is classified as invasive species due to the high competitiveness of natural regeneration and a significant increase in the renewal of autochthonous species in most European countries. In addition, there is a negative effect on the soil due to increased acidity, but on acid soils, the old arable and degraded lands, red oak has a number of advantages over autochthonous species. It is generalized that the distribution of red oak throughout Ukraine is unsystematic and its largest share is concentrated in the Western Forest-steppe; on the territory of Cherkassy Region only $3 \%$ of plantations grow along with its participation, and within the limits of Yurkivskyi Coal-mining Quarry there are only $2.2 \%$. We have revealed that red oak as phytomeliorant has the best soil-improving properties comparing to conifers, but worse in comparison with other deciduous ones on the re-cultivated lands of the Yurkiv Coal-mining Quarry. Red oak is presented in 9 plots with a total area of 14.1 hectares in the forest-melioration fund of the Yurkiv Coal-mining Quarry. The share of red oak in the forest stands ranges from 10 to $90 \%$, as well as in three plots up to $5 \%$. Trial plots were laid in three of these plantations and a detailed analysis of physical and chemical parameters of soil samples was carried out. For the purpose of biometric analysis of the growth of red oak and common oak on laid trial plots, one model tree was cut down and a detailed analysis of their growth was made. It has been found that in comparison with common oak the model trees of red oak are characterized by higher fullness of the trunk and better indicators of growth and productivity after the third grade of age when the root system does not receive an adequate amount of nutrients. Therefore, red oak is a perspective species for cultivation on degraded lands, but it is necessary to provide a distance at least $500 \mathrm{~m}$ from the objects of the nature reserve fund in order to prevent its spread to natural ecosystems.

Keywords: introduced plant; invasion; fullness; trunk taper; phytomeliorant. 